\title{
Ordovician enigmatic sclerite-type elements from western Argentina: possible oldest axial components of alcyonacean octocorals
}

\author{
Marcelo G. Carrera, Gustavo G. Voldman, Matias J. Mango, and Galina P. Nestell \\ Acta Palaeontologica Polonica 66 (3), 2021: 535-544 doi:https://doi.org/10.4202/app.00869.2020
}

The unusual findings of Lower and Middle Ordovician tiny sclerite-type elements in the San Juan Formation of the Argentine Precordillera are described and analysed. The well-preserved silicified and phosphatized association consists of spindle-shaped morphotypes, ornamented with small regular granules or tubercles with some elements connected by their tips in a linear manner. Some morphologic characteristics of these mostly fused or connected sclerite-type elements are present in the alcyonacean octocorals. Their affinities with sponge spicules are also discussed. The oldest records of alcyonacean sclerites have been dated as late Llandovery to late Wenlock (Silurian). The discovery of possible octocoral skeletal elements in the Lower Ordovician of western Argentina may represent the oldest occurrence of such fundamental skeletal elements in the evolutionary history of the octocorals. Although a proper group assignment is still speculative at this state of knowledge, there is an implication that these early forms could be axial skeletal elements comparable to those seen in the Scleraxonia or Calcaxonia octocorals. One new genus Catenatus and new species Catenatus argentinus are described.

Key words: Octocoralia, sclerite-type elements, Ordovician, Palaeozoic, Precordillera, Argentina.

Marcelo G. Carrera [mcarrera@unc.edu.ar], Gustavo G. Voldman [gvoldman@unc.edu.ar ], and Matías J. Mango [matiasjmango@gmail.com], CICTERRA (CONICET-Universidad Nacional de Córdoba), Facultad de Ciencias Exactas, Físicas y Naturales, Av. Vélez Sarsfield 1699, X5016GCA, Córdoba, Argentina. Galina P. Nestell [gnestell@uta.edu], Department of Earth and Environmental Sciences, University of Texas at Arlington, Arlington, Texas 76019, USA.

This is an open-access article distributed under the terms of the Creative Commons Attribution License (for details please see creativecommons.org), which permits unrestricted use, distribution, and reproduction in any medium, provided the original author and source are credited. 
FoF 5 Full text $(910.1 \mathrm{kB})$ 